\title{
Ascarid infection in wild Amur tigers (Panthera tigris altaica) in China
}

\author{
Zhi-wei Peng ${ }^{1 \dagger}$, Yao Ning ${ }^{1 \dagger}$, Dan Liu ${ }^{2}$, Ying Sun ${ }^{1}$, Li-xin Wang ${ }^{1}$, Qi-an Zhai ${ }^{1}$, Zhi-jun Hou ${ }^{1 *}$, Hong-liang Chai ${ }^{1 *}$ and \\ Guang-shun Jiang ${ }^{1 *}$
}

\begin{abstract}
Background: Wild Amur tigers are a sparsely populated species, and the conservation of this species is of great concern worldwide, but as an important health risk factor, parasite infection in them is not fully understanding.

Results: In this study, sixty-two faecal samples were collected to investigate the frequency and infection intensity of Toxocara cati and Toxascaris leonina in wild Amur tigers. The T. cati and T. leonina eggs were preliminary identified by microscopy, and confirmed by molecular techniques. Infection intensity was determined by the modified McMaster technique. Phylogenetic trees demonstrated that T. cati of wild Amur tiger had a closer relationship with which of other wild felines than that of domestic cats. T. leonina of Amur tiger and other felines clustered into one clade, showing a closer relationship than canines. The average frequency of $T$. cati was $77.42 \%$ (48/62), and the frequency in $2016(100 \%)$ were higher than those in $2013(P=0.051,<0.1 ; 66.6 \%)$ and $2014(P=$ $0.079,<0.1 ; 72.2 \%)$. The infection intensity of $T$. cati ranged from $316.6 \mathrm{n} / \mathrm{g}$ to $1084.1 \mathrm{n} / \mathrm{g}$. For $T$. leonina, only three samples presented eggs when the saturated sodium chloride floating method was performed, indicating that the frequency is $4.83 \%$ (3/62). Unfortunately, the egg number in faecal smears is lower than the detective limitation, so the infection intensity of $T$. leonina is missed.
\end{abstract}

Conclusions: This study demonstrated that ascarids are broadly prevalent, and T. cati is a dominant parasite species in the wild Amur tiger population.

Keywords: Wild Amur tiger, Toxocara cati, Toxascaris leonina, Infection rate, Infection frequency

\section{Background}

The Amur tiger (Panthera tigris altaica), also named as Siberian tiger, is a flagship species, which was distributed across the boarders of north-eastern China, the northern part of Korean Peninsula, and the southern part of the Russian Far East [1, 2]. Amur tigers are sanctioned China I level protected animals and are included in the Convention on International Trade in Endangered Species of Wild Fauna and Flora (CITES) Appendix I (https://www.

\footnotetext{
*Correspondence: houzhijundz@163.com; 17758625@qq.com; jgshun@126.com

'Zhi-wei Peng and Yao Ning contributed equally to this work.

'College of Wildlife and Protected Area, Northeast Forestry University, Harbin, China

Full list of author information is available at the end of the article
}

cites.org/eng/app/appendices.php) [3]. Fewer than 400 wild Amur tigers remain in Northeastern Asia, where they are primarily confined to the provinces of Primorye and Khabarovsk (the Russian Far East region) [4]. There are less than 20 Amur tigers distributed within the Changbaishan and Wandashan mountains of Northeast China [5].

Toxocara cati and Toxascaris leonina are common gastrointestinal parasites of cats [6,7], both species may affect host fitness and even impair host health $[8,9]$. Infection of Toxascaris is generally with considerably lower prevalence compared to Toxocara infections in domestic cats [10]. The prevalence of T. leonina was 5.9 to $30 \%$ in domestic cats [11-13], and the prevalence of $T$. cati was 7.2 to $83.3 \%$ has been showed in earlier studies [14-16].

(c) The Author(s). 2020 Open Access This article is licensed under a Creative Commons Attribution 4.0 International License, which permits use, sharing, adaptation, distribution and reproduction in any medium or format, as long as you give appropriate credit to the original author(s) and the source, provide a link to the Creative Commons licence, and indicate if changes were made. The images or other third party material in this article are included in the article's Creative Commons licence, unless indicated otherwise in a credit line to the material. If material is not included in the article's Creative Commons licence and your intended use is not permitted by statutory regulation or exceeds the permitted use, you will need to obtain permission directly from the copyright holder. To view a copy of this licence, visit http://creativecommons.org/licenses/by/4.0/ The Creative Commons Public Domain Dedication waiver (http://creativecommons.org/publicdomain/zero/1.0/) applies to the data made available in this article, unless otherwise stated in a credit line to the data. 
However, the situation in captive tiger populations is contrary to that of the domestic cat, a higher prevalence of $T$. leonina than $T$. cati was reported $[17,18]$. Ascarids infections have been reported in 3 fecal samples from wild Amur tiger [19]. To increase the knowledge of ascarid frequency in the wild tiger population, faecal samples were collected over a 5-year period in Northeast China and the infection frequency and intensity were analysed in the present study.

\section{Results}

The T. cati and T. leonina were recognized according to the morphological and molecular characteristics of the eggs present in wild Amur tiger faecal samples. The sequences have been deposited in GenBank under the accession numbers MK381263 (T. cati) and MK381264 (T. leonina).

The frequency of $T$. cati ranged from 66.6 to $100 \%$ in 5 years, and the average frequency was $77.42 \%$ (95\% CI: 65.59-86.04\%) (Table 1). The frequency in 2016 was higher than those in $2013(P=0.051,<0.1)$ and 2014 $(P=0.079,<$ 0.1 ) (Table 1$)$. The infection intensity of $T$. cati fluctuated over the five-year period from $316.6 \mathrm{n} / \mathrm{g}$ to $1084.1 \mathrm{n} / \mathrm{g}$, and the average intensity was $528 \mathrm{n} / \mathrm{g}$ (Table 1 ).

For $T$. leonina, only three samples presented eggs when the saturated sodium chloride floating method was performed, indicating that the frequency was $4.83 \%$ (3/ 62 ). Unfortunately, the egg number in faecal was lower than the detective limitation, so the infection intensity of T. leonina was missed.

Within the T. leonina internal transcribed spacer 1 (ITS-1) partial nucleotide sequences of four captive tigers (two Amur, one South China tiger, and one Indochinese tiger) and one wild Amur tiger, there were insertion and transversion observed in the South China tiger (Panthera tigris amoyensis) and wild Amur tiger, respectively (Table 2).

By comparing ML, MP and BI phylogenetic trees, the results demonstrated that $T$. cati of wild Amur tiger had a closer relationship with which of other wild felines than that of domestic cats. T. leonina of Amur tiger and other felines clustered into one clade, showing a closer relationship than canines (Fig. 1).

\section{Discussion}

In the zoo, the Amur had a seriously T. leonina (104 n/g, 61.7\%) and T. cati $(56.36 \mathrm{n} / \mathrm{g}, 49.5 \%)$ co-prevalence [17]. In the present study, the infection intensity of $T$. leonina was lower than the detective limitation $(60 \mathrm{n} / \mathrm{g})$ and the frequency was $4.83 \%$; but the average infection intensity and the frequency of $T$. cati were $528 \mathrm{n} / \mathrm{g}$ and $77.42 \%$, respectively. This illustrated that $T$. cati was only the dominant parasite in the wild Amur tiger population and have a different frequency status comparing with tiger in the zoo. Parasitic infection causes certain effects on immune system [20] and predispose factors for viral infections [21], and also vice versa; viral infections lowering immunity of hosts [21] and the target be liable for severe effects of parasites. As the canine distemper virus has been a risk factor for the Amur tiger [22], co-infection with ascarid will aggravated the health threat. Additional, another situation also needed to be paid an attention. The Amur tiger, a typical solitary carnivore, have a so big habit approximately $400-600 \mathrm{~km}^{2}$ [23]; it is hard to understand how $T$. cati, a generally monoxenous nematode, could keep the effective transmission among Amur tigers in the field as in the zoo except the paratenic hosts play a role.

Interestingly, wild Amur tiger show a strong preference for wild boar as diet, which were also the most frequently consumed prey [24, 25]. Similarly, the wild boar could take both rodents and earthworm as its diet [26], as well as the earthworm appeared in the diets of the rodent [27]. Besides, the earthworm could carry $T$. cati $[28,29]$, and $T$. cati appeared in wild boars and rodents served as potential paratenic hosts of $T$. cati, and contributed to persisting in the environment have been found [30,31]. If the rodent, which taken larva of $T$. cati from earthworm, was preyed by the wild boar, as well as the wild boar, it taken larva of T. cati from earthworm or from rodent, was preyed by the tiger, the tiger will be infected by the $T$. cati through this food-chain transmission way (Fig. 2). Then, a hypothesis, $T$. cati transmitted in wild tigers with a special route including paratenic hosts participating was deduced. Actually, the parasites of wild carnivores take the prey as the paratenic host to spread have been showed [32-34], and it

Table 1 Comparison of the differences in infection intensity and frequency of T. cati from 2012 to 2016

\begin{tabular}{llllll}
\hline & Total number & Infection number & Average infection intensity $(\mathrm{n} / \mathrm{g}) \pm$ SD & Frequency* (\%) & $95 \%$ Confidence interval (\%) \\
\hline 2012 & 8 & 7 & $510.0 \pm 903.7$ & $87.5 \%$ abc & $52.91-97.76$ \\
2013 & 15 & 10 & $380.0 \pm 783.7$ & $66.6 \% \mathrm{c}$ & $41.71-84.82$ \\
2014 & 18 & 13 & $394.4 \pm 934.2$ & $72.2 \%$ bc & $49.13-87.5$ \\
2015 & 12 & 9 & $1084.1 \pm 1578.4$ & $75 \%$ abc & $46.77-91.11$ \\
2016 & 9 & 9 & $316.6 \pm 378.6$ & $100 \%$ a & $70.09-100$ \\
Total & 62 & 48 & $528.0 \pm 1012.0$ & $77.42 \%$ & $65.59-86.04$ \\
\hline
\end{tabular}

Note: ${ }^{*} P<0.1 ; \mathrm{n} / \mathrm{g}$ : the number of eggs/gram faeces 
Table 2 Position of insertion or transversion in ITS partial gene sequences of T.leonina in Chinese Tiger and wild Amur Tiger respectively

\begin{tabular}{llllll}
\hline \multirow{2}{*}{$\begin{array}{l}\text { Nucleotide } \\
\text { position }\end{array}$} & \multicolumn{4}{l}{ Accession Number and Host } \\
\cline { 2 - 6 } & JF837175 Amur & JF837177 Indochinese & JF837178 South China & $\begin{array}{l}\text { MK381264 Amur } \\
\text { tiger }^{\mathrm{a}}\end{array}$ & $\begin{array}{l}\text { Unpublished Amur } \\
\text { tiger }\end{array}$ \\
\hline $24-25$ & tiger & - & tiger & - & - \\
305 & G & G & G & A & G \\
\hline
\end{tabular}

Note: ${ }^{\text {a }}$ indicated that is wild, others are captured in Zoo

is a more reasonable transmission way as the carnivore hosts always have large habits and the oral-faecal transmitting route is impractical in the field. If the speculation we conducted is certified in the future, it will benefit the understanding how $T$. cati spreads in wild big felines efficiently.

The co-evolution between parasites and hosts has been shown in different studies [35-37]. Parasites are generally viewed as having a higher evolutionary potential than their hosts $[37,38]$. This may be especially true when parasites have shorter generation times, larger population sizes, higher migration and mutation rates than their hosts [39,
40]. There may be another case between tiger and T. cati, as indicated by the results of the present study. Phylogenetic relations among felid species showed that the divergence time $(\mathrm{Ma})$ of the tiger, Asian golden cat, Asian leopard cat, and cat lineages (jungle cat and domestic cat) were $10.78 \mathrm{Ma}, 9.43 \mathrm{Ma}, 6.18 \mathrm{Ma}$, and $3.36 \mathrm{Ma}$, respectively [41]. Interestingly, $T$. cati of the tiger and golden cat diverged first, followed by the leopard cat, jungle cat, and domestic cat (Fig. 1), which coincided with the divergence of these felid hosts. It is supposed that $T$. cati may have evolved into different subspecies or strains to orient to feline host divergence.

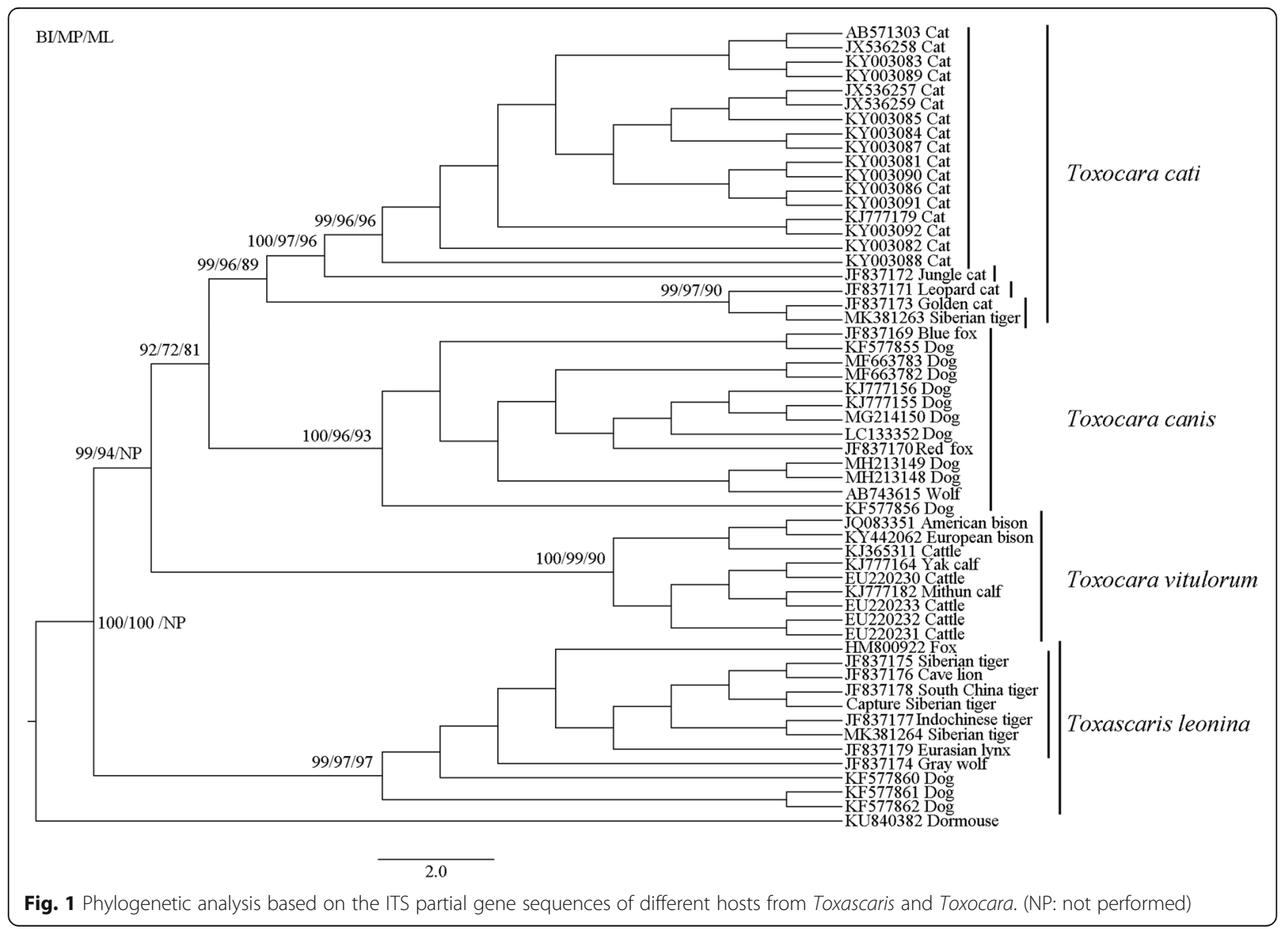




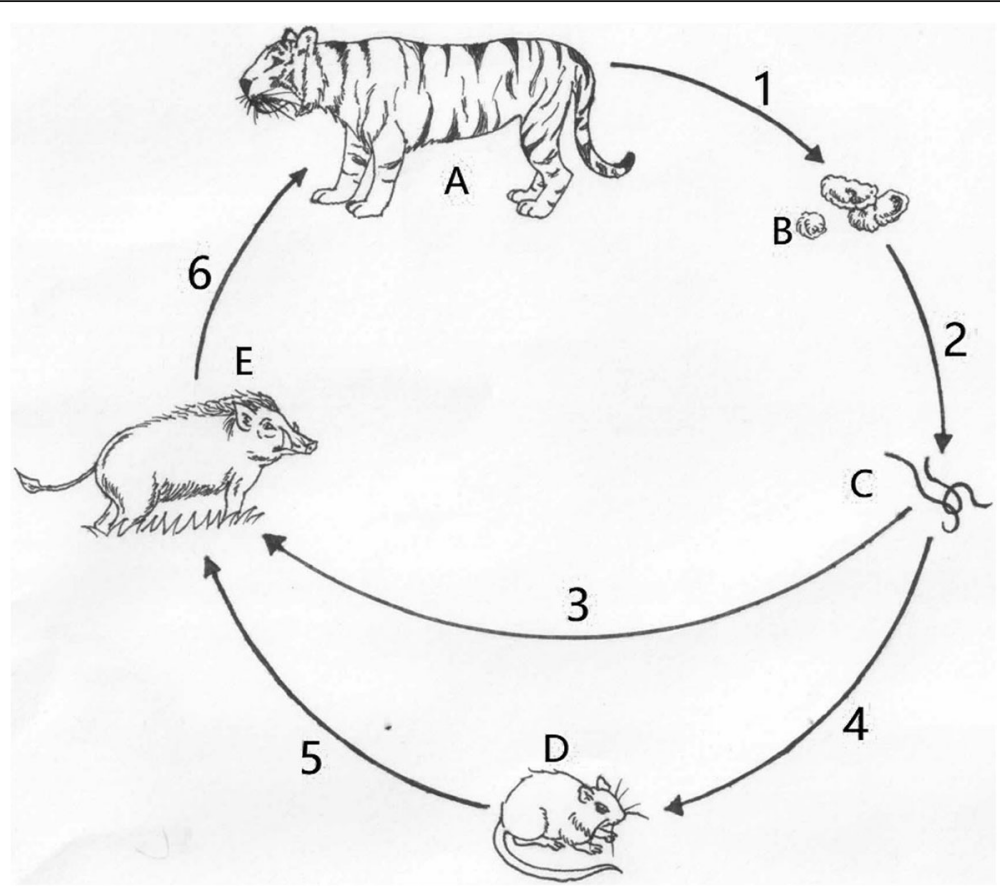

Fig. 2 The speculative life history of the Toxocara cati in wild Amur tiger. A: Tiger host; B: Eggs in the faecals; C: Earthworm; D: Rodents; E: Wild boar. 1: The eggs of T.cati was discharged into environment with faecal of tiger; 2: The eggs of T.cati in environment was taken by the earthworm. 3: The earthworm was taken by the wild boar; 4: The earthworm was taken by the rodent; 5: The rodent was taken by the wild boar; 6: The wild boar was preyed by the tiger

\section{Conclusions}

The results of this study demonstrate that $T$. cati is a dominant parasite species in the wild Amur tiger population.

\section{Methods}

\section{Sample collection and parasites separation}

In current work, approved by the local government agents, sixty-two faecal samples of wild Amur tiger were collected during 2012 to 2016 in northeast China from the environment (Fig. 3). Most of them were collected in the Hunchun Amur Tiger National Reserve (HNR), which is a key corridor for movement of Amur tigers among China, Russia and North Korea [24]. Those samples were collected in winter or spring when the project of snow-tracking individual tigers was taken; at that time, the local temperature is absolutely below $0{ }^{\circ} \mathrm{C}$. When samples were brought back to the laboratory, they were stored frozen at $-80^{\circ} \mathrm{C}$. The feces samples were confirmed belonging to tigers were taken by a specific molecular method [2]. The T. cati and $T$. leonina eggs were separated with a saturated solution of sodium chloride as the floating medium and identified based on the morphological characteristics [19]. After preliminary identification, the identity of different eggs was confirmed by the polymerase chain reaction (PCR). Infection intensity was determined by the modified McMaster technique [42]. The minimum limit for the infection intensity of $T$. cati and T. leonina was $60 \mathrm{n} / \mathrm{g}$.

\section{DNA extraction and PCR amplification}

DNA extraction was performed using a QIAmp DNA Stool Mini Kit (Qiagen Germany) following the manufacturer's instructions. The partial ITS fragment $(727 \mathrm{bp})$ of T. cati was amplified by PCR using a set of primers, including the forward primer FM1: 5'-TTGAGGGGAA ATGGGTGAC-3' and reverse primer FM2: 5' -TGCTGG AGGCCATATCGT-3' [43]. The partial ITS sequence (452 bp) of $T$. leonina was amplified by universal primers: forward primer S1: 5'-TGCGTTCTTCATCGATCCAC$3^{\prime}$ and reverse primer S2: 5' -AAAGTCTCCAAACGTG CAT-3'. PCR reactions were carried out in a final volume of $25 \mu \mathrm{l}$, including $2 \mathrm{mM} \mathrm{MgCl}_{2}, 2.5 \mathrm{mM}$ each dNTP, 10× Takara buffer, 100 pmol each primer, $1.25 \mathrm{U}$ Takara polymerase (Takara), and $1 \mu \mathrm{L}$ of DNA sample in a thermocycler (BioRad) under the following conditions: initial denaturation at $94{ }^{\circ} \mathrm{C}$ for $5 \mathrm{~min}, 30$ cycles at $94{ }^{\circ} \mathrm{C}$ for $30 \mathrm{~s}$ (denaturation), $60^{\circ} \mathrm{C}\left(\right.$ T. cati) or $50^{\circ} \mathrm{C}$ (T. leonina) for $30 \mathrm{~s}$ for annealing, $68^{\circ} \mathrm{C}$ for $1 \mathrm{~min}$ for extension, followed by a final extension at $72^{\circ} \mathrm{C}$ for $8 \mathrm{~min}$. PCR yielded a single band detected in a $1 \%(\mathrm{w} / \mathrm{v})$ agarose gel upon ethidium bromide staining. PCR products were purified using a Takara minibest agarose gel DNA extraction kit (Takara, Japan) according to the manufacturer's procedure and sent 


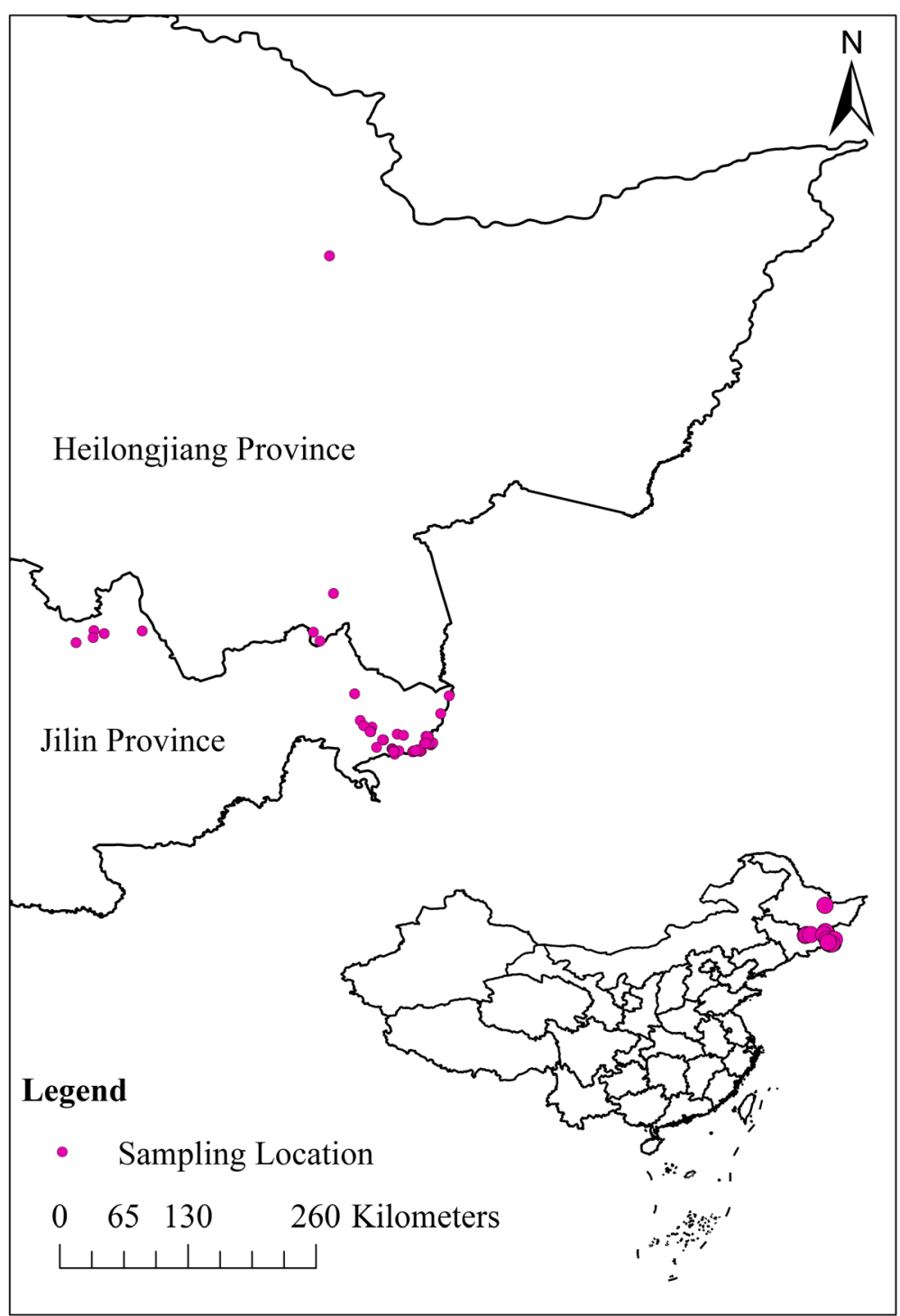

Fig. 3 Locations of the Amur tiger faecal sampling sites used in this research

to Comate Biosciences Co., Ltd. (Changchun, China) for sequencing. For more precision, sequencing of amplicons was performed in both directions (forward and reverse).

\section{Phylogenetic analysis}

The construction of the phylogenetic trees was hypothesized using maximum parsimony (MP), maximum likelihood (ML), and bayesian inference (BI). MP analyses were conducted using PAUP* version 4.0b10 [44]. All characters were weighted equally and unordered, and only potentially phylogenetically informative sites were retained for tree searching. Analyses used a heuristic search with 1000 random stepwise additions followed by tree bisection reconnection (TBR) branch swapping. MP bootstrap branch support values were calculated with 1000 pseudoreplicates with ten random- addition sequences performed in each replication. ML analysis was carried out by MEGA 6.0 with 1000 bootstrap replicates for the estimation of branch support. For BI, the best-fitting models for sequences were $\mathrm{HKY}+\mathrm{G}$, which was selected by using Akaike's information criterion (AIC) as implemented in MODELTEST3.7 [45], and the following settings were applied: 3 million Markov Chain Monte Carlo (MCMC) generations, with a sampling frequency of 100. The first one-fourth generations were discarded as burn-in. The remaining samples were used to generate a majority-rule consensus tree. The frequency of resolving a node was termed a Bayesian posterior probability (BPP). All MCMC runs were repeated twice to confirm a consistent approximation of the posterior parameter distributions. The partial ITS sequence for Hymenolepis sp. (GenBank: KU840382) was used as the outgroup. 


\section{Statistical analysis}

The old faecal samples collected in the wild environment did not allow the individual animal identification and it cannot exclude that some faecal samples belonged to the same animal. Therefore, this study used the term frequency and not prevalence to describe the proportion of T. cati infections in the wild Amur tiger population investigated [46]. The Pnorm function was used to calculate the significant differences in frequency (\%), and 95\% confidence interval (CI) was calculated in PropCIs function in $\mathrm{R}$ version 3.5.2.

\section{Abbreviations}

AIC: Akaike's information criterion; BI: Bayesian inference; BPP: Bayesian posterior probability; Cl: Confidence interval; CITES: Convention on International Trade in Endangered Species; HNR: Hunchun Amur Tiger National Reserve; ITS: Internal transcribed spacer; Ma: Megaannus; MCMC: Markov chain monte carlo; ML: Maximum likelihood; MP: Maximum parsimony; PCR: Polymerase chain reaction; T. cati: Toxocara cati; $T$. leonina: Toxascaris leonina; TBR: Tree bisection reconnection

\section{Acknowledgements}

Not applicable.

\section{Authors' contributions}

$\mathrm{ZH}$ and GJ conceived the project. ZP carried out laboratory work and wrote the manuscript. YN, DL collected samples. ZP, YS, LW, QZ, HC performed the data analyses. All authors have read and approved the manuscript.

\section{Funding}

This study was supported by the National Key Research and Development Program of China (No.2017YFD05011702). The Fundamental Research Funds for the Central Universities (No.2572018AA29), and Surveillance of Wildlife Diseases from the National Forestry and Grassland Administration of China (No. 2019076017). This funding body provided monetary support only and did not have any input into the design of the study, collection, analysis, and interpretation of data.

\section{Availability of data and materials}

The datasets supporting the findings of this article are included within the article. In wild Amur tiger, GenBank accession numbers of T.cati is MK381263 and T. leonina is MK381264. For other particular data of T.cati, GenBank accession numbers are AB571303, JX536258, KY003083, KY003089, JX536257, JX536259, KY003085, KY003084, KY003087, KY003081, KY003090, KY003086, KY003091, KJ777179, KY003092, KY003082, KY003088, JF837172, JF837171 and JF837173. For other particular data of T.leonina, GenBank accession numbers are HM800922, JF837175, JF837176, JF837178, JF837177, JF837179, JF837174, KF577860, KF577861 and KF577862. For Toxocara canis and Toxocara vitulorum, GenBank accession numbers are shown in Fig. 1.

\section{Ethics approval and consent to participate}

We declare that all samples from the wild Amur tiger was approved by the local Jilin and Heilongjiang provience government agents. There is no conflict of interest with species conservation guidelines. All experimental designs and animals handling were approved by the Institutional Animal Care and Use Committee of Northeast Forestry University.

\section{Consent for publication}

Not applicable.

\section{Competing interests}

The authors declare that they have no competing interests.

\section{Author details}

${ }^{1}$ College of Wildlife and Protected Area, Northeast Forestry University, Harbin, China. ${ }^{2}$ Amur Tiger Pk, Harbin, Heilongjiang, China.
Received: 4 September 2019 Accepted: 21 February 2020

Published online: 10 March 2020

\section{References}

1. Sugimoto T, Nagata J, Aramilev W, McCullough DR. Population size estimation of Amur tigers in Russian Far East using noninvasive genetic samples. J Mammal. 2012;93(1):93-101.

2. Ning Y, Kostyria AV, Ma JZ, Chayka MI, Guskov VY, Qi JZ, Sheremetyeva IN, Wang M, Jiang GS. Dispersal of Amur tiger from spatial distribution and genetics within the eastern Changbai mountains of China. Ecol Evol. 2019;9: 2415-24.

3. Guo Y, Liu CQ, Lu TF, Liu D, Bai CY, Li XC, Ma YH, Guan WJ. Generation and analysis of a large-scale expressed sequence tags from a full-length enriched cDNA library of Siberian tiger (Panthera tigris altaica). Gene. 2014; 541(2):75-81.

4. Miquelle DG, Pikunov DG, Dunishenko YM, Aramilev W, Nikolaev IG, Abramov VK, Smirnov EN, Salkina GP, Seryodkin IV, Gaponov W, Fomenko PV, Litvinov MN, Kostyria AV, Yudin VG, Korkisko VG, Murzin AA. 2005 Amur tiger census. Cat News. 2007;46:14-6.

5. Kerley LL, Mukhacheva AS, Matyukhina DS, Salmanova E, Salkina GP Miquelle DG. A comparison of food habits and prey preference of Amur tiger (Panthera tigris altaica) at three sites in the Russian Far East. Integr Zool. 2015;10(4):354-64.

6. He X, Lv MN, Liu GH, Lin RQ. Genetic analysis of Toxocara cati (Nematoda: Ascarididae) from Guangdong province, subtropical China. Mitochondrial DNA A DNA Mapp Seq Anal. 2018;29(1):1-4.

7. Okulewicz A, Lonc E, Borgsteede FH. Ascarid nematodes in domestic and wild terrestrial mammals. Pol J Vet Sci. 2002;5(4):277-81.

8. Li KX, Yang F, Abdullahi AY, Song MR, Shi XL, Wang MW, Fu YQ, Pan WD, Shan F, Chen W, Li GQ. Sequence analysis of mitochondrial genome of Toxascaris leonina from a South China tiger. Korean J Parasitol. 2016;54(6): 803-7.

9. Overgaauw PAM, van Knapen F. Veterinary and public health aspects of Toxocara spp. Vet Parasitol. 2013;193(4):398-403.

10. Parsons JC. Ascarid infections of cats and dogs. Vet Clin North Am Small Anim Pract. 1987;17(6):1307-39.

11. Hajipour N, Imani Baran A, Yakhchali M, Banan Khojasteh SM, Sheikhzade Hesari F, Esmaeilnejad B, Arjmand J. A survey study on gastrointestinal parasites of stray cats in Azarshahr, (East Azerbaijan province, Iran). J Parasit Dis. 2016;40(4):1255-60.

12. Martinković F, Sindičić M, Lučinger S, Štimac I, Bujanić M, Živičnjak T, Stojčević Jan D, Šprem N, Popović R, Konjević D. Endoparasites of wildcats in Croatia. Vet Arhiv. 2017:87(6):713-29.

13. Yakhchali M, Hajipour N, Malekzadeh-Viayeh R, Esmaeilnejad B, NematiHaravani T, Fathollahzadeh M, Jafari R. Gastrointestinal helminths and ectoparasites in the stray cats (Felidae: Felis catus) of Ahar municipality, Northwestern Iran. Iran J Parasitol. 2017;12(2):298-304.

14. Giannelli A, Capelli G, Joachim A, Hinney B, Losson B, Kirkova Z, RenéMartellet M, Papadopoulos E, Farkas R, Napoli E, Brianti E, Tamponi C, Varcasia A, Margarida Alho A, Madeira de Carvalho L, Cardoso L, Maia C, Mircean V, Mihalca AD, Miró G, Schnyder M, Cantacessi C, Colella V, Cavalera MA, Latrofa MS, Annoscia G, Knaus M, Halos L, Beugnet F, Otranto D. Lungworms and gastrointestinal parasites of domestic cats: a European perspective. Int J Parasitol. 2017:47(9):517-28.

15. Knaus M, Kusi I, Rapti D, Xhaxhiu D, Winter R, Visser M, Rehbein S. Endoparasites of cats from the Tirana area and the first report on Aelurostrongylus abstrusus (Railliet, 1898) in Albania. Wien Klin Wochenschr. 2011;123(1):31-5.

16. Kostopoulou D, Claerebout E, Arvanitis D, Ligda P, Voutzourakis N, Casaert S, Sotiraki S. Abundance, zoonotic potential and risk factors of intestinal parasitism amongst dog and cat populations: the scenario of Crete, Greece. Parasit Vectors. 2017;10(1):43.

17. Peng ZW, Liu SJ, Hou ZJ, Xing MW. Ascarid infestation in captive Siberian tigers in China. Vet Parasitol. 2016;226:74-7.

18. Liu JL, Hou ZJ, Hua YP, Liu D, Wang W. Survey of endoparasites infection in feline animals in the Heilongjiang Amur tiger park, China. Chin J Wildlife. 2007:03:26-8 (in Chinese).

19. González P, Carbonell E, Urios V, Rozhnov W. Coprology of Panthera tigris altaica and Felis bengalensis euptilurus from the Russian Far East. J Parasitol. 2007;93(4):948-50 
20. Bany J. Immunosuppressive effect of parasitic infection on the immune system of the host: suppression of the graft vs host reaction in experimental trichinosis in mice. Wiad Parazytol. 1985;31(4-6):549-50.

21. Nolan D, Gaudieri S, Mallal S. Host genetics and viral infections: immunology taught by viruses, virology taught by the immune system. Curr Opin Immunol. 2006;18(4):413-21.

22. Appel MJ, Yates RA, Foley GL, Bernstein JJ, Santinelli S, Spelman LH, Miller LD, Arp LH, Anderson M, Barr M, Pearce-Kelling S, Summers BA. Canine distemper epizootic in lions, tigers, and leopards in North America. J Vet Diagn Investig. 1994;6(3):277-88.

23. Goodrich JM, Miquelle DG, Smirnov EN, Kerley LL, Quigley HB, Hornocker MG. Spatial structure of Amur (Siberian) tigers (Panthera tigris altaica) on Sikhote-Alin biosphere Zapovednik, Russia. J Mammal. 2010;91(3):737-48.

24. Gu JY, Yu L, Hua Y, Ning Y, Bao H, Qi JZ, Long ZX, Yao MY, Huang C, Li ZL, Lang JM, Jiang GS, Ma JZ. A comparison of food habits and prey preferences of Amur tiger (Panthera tigris altaica) at the southwest Primorskii Krai in Russia and Hunchun in China. Integr Zool. 2018;13(5): 595-603.

25. Sugimoto T, Aramilev W, Nagata J, McCullough DR. Winter food habits of sympatric carnivores, Amur tigers and far eastern leopards, in the Russian Far East. Mamm Biol. 2016:81(2):214-8.

26. Robeson MS, Khanipov K, Golovko G, Wisely SM, White MD, Bodenchuck M, Smyser TJ, Fofanov Y, Fierer N, Piaggio AJ. Assessing the utility of metabarcoding for diet analyses of the omnivorous wild pig (Sus scrofa). Ecol Evol. 2018;8(1):185-96.

27. Jin ZM, Liu Z, Li DW, Zhang HW, Yang CY. Analysis on the feeding habits of six kinds of rodents in the southeast forest region of Heilongjiang Province. Animal Husbandry Feed Sci. 2011;32(5):11-3 (in Chinese).

28. Mizgajska H. Eggs of Toxocara spp. in the environment and their public health implications. J Helminthol. 2001;75(2):147-51.

29. Cianferoni A, Schneider L, Schantz PM, Brown D, Fox LM. Visceral larva migrans associated with earthworm ingestion: clinical evolution in an adolescent patient. Pediatrics. 2006;117:e336-9.

30. Antolová D, Reiterová K, Dubinsky P. The role of wild boars (Sus scrofa) in circulation of trichinellosis, toxocarosis and ascariosis in the Slovak Republic. Helminthologia. 2006:43(2):92-7.

31. Taira K, Yanagida T, Akazawa N, Saitoh Y. High infectivity of Toxocara cati larvae from muscles of experimentally infected rats. Vet Parasitol. 2013; 196(3-4):397-400

32. Alić A, Traversa D, Duscher GG, Kadrić M, Di Cesare A, Hodžić A. Troglostrongylus brevior in an Eurasian lynx (Lynx lynx) from Bosnia and Herzegovina. Parasit Vectors. 2015;8(1):1-5.

33. Colella V, Knaus M, Lai O, Cantile C, Abramo F, Rehbein S, Otranto D. Mice as paratenic hosts of Aelurostrongylus abstrusus. Parasit Vectors. 2019;12(49):49.

34. Yoshida A, Matsuo K, Moribe J, Tanaka R, Kikuchi T, Nagayasu E, Misawa N, Maruyama $\mathrm{H}$. Venison, another source of Paragonimus westermani infection. Parasitol Int. 2016;65(6):607-12.

35. Ebert D. Host-parasite coevolution: insights from the daphnia-parasite model system. Curr Opin Microbiol. 2008;11(3):290-301.

36. Morand S, Manning SD, Woolhouse ME. Parasite-host coevolution and geographic patterns of parasite infectivity and host susceptibility. Proc Biol Sci. 1996;263(1366):119-28.

37. Schneider LD, Nilsson PA, Höjesjö J, Österling EM. Local adaptation studies and conservation: parasite-host interactions between the endangered freshwater mussel Unio crassus and its host fish. Aquat Conserv. 2017;27(6): 1261-9.

38. Gandon S, Michalakis Y. Local adaptation, evolutionary potential and hostparasite coevolution: interactions between migration, mutation, population size and generation time. J Evol Biol. 2010;15(3):451-62

39. Lively CM, Dybdahl MF. Parasite adaptation to locally common host genotypes. Nature. 2000;405(6787):679.

40. Morgan AD, Buckling A. Relative number of generations of hosts and parasites does not influence parasite local adaptation in coevolving populations of bacteria and phages. J Evol Biol. 2010;19(6):1956-63.

41. Johnson WE, Eizirik E, Pecon-Slattery J, Murphy WJ, Antunes A, Teeling E, O'Brien SJ. The late miocene radiation of modern felidae: a genetic assessment. Science. 2006:311(5757):73-7.

42. Nwosu CO, Madu PP, Richards WS. Prevalence and seasonal changes in the population of gastrointestinal nematodes of small ruminants in the semiarid zone of North-Eastern Nigeria. Vet Parasitol. 2007;144(1):118-24.
43. Mikaeili F, Mathis A, Deplazes P, Mirhendi H, Barazesh A, Ebrahimi S, Kia EB. Differentiation of Toxocara canis and Toxocara cati based on PCR-RFLP analyses of rDNA-ITS and mitochondrial Cox1 and nad1 regions. Acta Parasitol. 2017;62(3):549-56.

44. Cummings MP. PAUP* [phylogenetic analysis using parsimony (and other methods)]. Dictionary of Bioinformatics and Computational Biology. Colchester: Wiley; 2004.

45. Ronquist F, Huelsenbeck JP. MrBayes 3: Bayesian phylogenetic inference under mixed models. Bioinformatics. 2003;19(12):1572-4.

46. Gori F, Armua-Fernandez MT, Milanesi P, Serafini M, Magi M, Deplazes P, Macchioni $F$. The occurrence of taeniids of wolves in Liguria (northern Italy). Int J Parasitol Parasites Wildl. 2015;4(2):252-5.

\section{Publisher's Note}

Springer Nature remains neutral with regard to jurisdictional claims in published maps and institutional affiliations.
Ready to submit your research? Choose BMC and benefit from:

- fast, convenient online submission

- thorough peer review by experienced researchers in your field

- rapid publication on acceptance

- support for research data, including large and complex data types

- gold Open Access which fosters wider collaboration and increased citations

- maximum visibility for your research: over $100 \mathrm{M}$ website views per year

At BMC, research is always in progress.

Learn more biomedcentral.com/submissions 